\title{
Cytocompatibility of Ti-xZr alloys as dental implant materials
}

\author{
Pinghua $\mathrm{Ou}^{1,2} \cdot$ Cong $\mathrm{Hao}^{3} \cdot$ Jue $\mathrm{Liu}^{4} \cdot$ Rengui $\mathrm{He}^{1} \cdot$ Baoqi Wang ${ }^{1} \cdot$ Jianming Ruan $\mathbb{1}^{1}$
}

Received: 3 July 2020 / Accepted: 1 April 2021 / Published online: 23 April 2021

(c) The Author(s) 2021

\begin{abstract}
$\operatorname{Ti}-x Z r(x=5,15,25,35,45 \%$ wt $\%)$ alloys with low elastic modulus and high mechanical strength were fabricated as a novel implant material. The biocompatibility of the Ti-xZr alloys was evaluated by osteoblast-like cell line (MG63) in terms of cytotoxicity, proliferation, adhesion, and osteogenic induction using CCK-8 and live/dead cell assays, electron microscopy, and real-time PCR. The Ti-xZr alloys were non-toxic and showed superior biomechanics compared to commercially pure titanium (cpTi). Ti-45Zr had the optimum strength/elastic modulus ratio and osteogenic activity, thus is a promising to used as dental implants.
\end{abstract}

\section{Introduction}

Tooth loss is a common problem that can weaken chewing function, and even lead to more serious complications such as alveolar bone atrophy, masticatory muscle atrophy, facial collapse, etc. Dental implants are routinely used in oral rehabilitation to replace lost teeth (unitary or total), and have improved patient quality of life [1]. Pure titanium (Ti) is a standard dental implant material owing to its excellent mechanical properties and good biocompatibility [2, 3]. However, the tensile strength of commercially pure titanium (cpTi) is low, which can result in implant fractures, especially in individuals that exhibit bruxism [4]. In addition, Wachi et al. reported that the Ti ions released from these implants can trigger peri-implant mucositis, which eventually progress to peri-implantitis accompanied by alveolar bone resorption [5]. Therefore, different metal alloys are being considered due to their enhanced mechano-physical

$\triangle$ Jianming Ruan

jianming@csu.edu.cn

1 State Key Laboratory of Powder Metallurgy, Central South University, Changsha 410083, PR China

2 Department of Stomatology, Third Xiangya Hospital, Central South University, Changsha 410013, PR China

3 Department of Orthopedics, Xiangya Hospital Central South University, Changsha 410008 Hunan, PR China

4 Hunan Province Key Laboratory of Engineering Rheology, Central South University of Forestry and Technology, Changsha 410004, PR China properties, which can potentially improve the clinical performance of the implants [6]. For instance, the Ti-6Al-4V alloy is increasingly replacing cpTi on account of its greater strength [7] and enhanced mechanical performance [8]. However, it is biomechanically incompatible to the human bone due to threefold higher Young's elastic modulus ( $110 \mathrm{GPa}$ compared to human bones), which results in the "stress shielding effect" on the supporting tissues [9]. Furthermore, the vanadium $(\mathrm{V})$ ions released into the blood and urine [10] can initiate an inflammatory cascade leading to osteolysis [11, 12], and aluminum (Al) ions are frequently present in the brain tissues of Alzheimer's disease patients, which indicates a neurodegenerative effect [13]. Therefore, there is an urgent need to synthesize novel alloys with high mechanical strength and biocompatibility, and low elastic modulus.

Zirconium ( $\mathrm{Zr}$ ), a transient element belonging to Group 4 (according to new IUPAC name) in the periodic table, is chemically similar to $\mathrm{Ti}$ and does not display any local or systemic toxic effects [14]. The elastic modulus of $\mathrm{Zr}$ is $88 \mathrm{GPa}$, which is closer to that of the bone. Abdullah et al. compared $\mathrm{Ti}$ and $\mathrm{Zr}$ implants in a rabbit model, and observed similar bone contact with both, although $\mathrm{Zr}$ had superior biomechanics due to lower elasticity. In addition, the $\mathrm{Zr}$ ions released from the implant further increased the bone response [15]. Kobayashi et al. first proposed the biomedical application of Ti-Zr alloys in 1995 based on their superior mechanical and tensile strength [16]. Furthermore, binary $\mathrm{Ti}-\mathrm{Zr}$ alloys with $\mathrm{Ti}$ as the primary component have shown encouraging results as dental implants [17, 18], in terms of both biomechanics $[19,20]$ and bioactivity [21]. The binary $\mathrm{Ti}-\mathrm{Zr}$ alloy with $13 \sim 17 \% \mathrm{Zr}$ is 
currently marketed as an implant material under the trade name Roxolid. In addition, equiatomic $\mathrm{Ti}-\mathrm{Zr}$ alloys have also demonstrated excellent mechanical properties and good corrosion resistance [22, 23]. Kobayashi et al. found that Ti-Zr binary alloys with $30-60 \% \mathrm{Zr}$ have higher Vickers hardness and superior tensile strength [24], which was confirmed by another study that observed higher microhardness and bending strength of Ti-Zr alloy with $40 \% \mathrm{Zr}$ (Ti-40Zr) [25, 26]. Teisuke et al. found that $\mathrm{Ti}-30 \mathrm{Zr}$ or alloys with $>50 \% \mathrm{Zr}$ were ideal for clinical applications in terms of corrosion resistance [27]. Taken together, $\mathrm{Ti}-\mathrm{Zr}$ alloys are a mechanically improved alternative to cpTi with similar biocompatibility, and can reduce the risk of implant fracture.

However, the optimal proportion of $\mathrm{Zr}$ and $\mathrm{Ti}$ for dental applications has not been established. We recently prepared $\mathrm{Ti}-\mathrm{xZr}$ alloys with varying amounts of $\mathrm{Zr}(x=5,15,25,35$, $45 \% \mathrm{wt} \%$ ) by combining powder metallurgy with heat treatment. The Ti-xZr alloys exhibited maximum bending strength of $867.1 \mathrm{MPa}$ and maximum compressive strength of $1599.8 \mathrm{MPa}$, which are superior to that of cpTi. Furthermore, all $\mathrm{Ti}-\mathrm{Zr}$ alloys showed a lower elastic modulus (53.5-59.3 GPa) compared to cpTi (103 GPa) [28]. However, the biocompatibility of these binary alloys also need to be determined for any future clinical applications. To this end, we analyzed the cytocompatibility and osteogenic activity of $\mathrm{Ti}-\mathrm{xZr}$ alloys in vitro to ascertain the optimal $\mathrm{Zr}$ concentration for dental implants.

\section{Materials and methods}

\subsection{Preparation of $\mathrm{Ti}-\mathrm{Zr}$ alloys}

The $\mathrm{Ti}-\mathrm{Zr}$ alloys comprising of $5-45 \% \mathrm{Zr}$ by weight were prepared by powder metallurgy as described previously [28]. Pure $\mathrm{Ti}$ and $\mathrm{Zr}$ were supplied by Zhongzhou Alloy Material Co. Ltd. The chemical composition is presented in Table 1.

\subsection{Preparation of alloy specimens}

$\mathrm{Ti}$ and $\mathrm{Zr}$ discs measuring $10 \mathrm{~mm}$ in diameter and $1 \mathrm{~mm}$ in thickness were polished using silicon carbide papers up to 1200 grit. After sequential cleansing with acetone, ethanol

Table 1 The impurities of in $\mathrm{Ti}$ and $\mathrm{Zr}$ powder

\begin{tabular}{llllll}
\hline Powder & Purity (\%) & $\mathrm{C}(\mathrm{wt} \%)$ & $\mathrm{O}(\mathrm{wt} \%)$ & $\mathrm{N}(\mathrm{wt} \%)$ & $\mathrm{H}(\mathrm{wt} \%)$ \\
\hline $\mathrm{Ti}$ & 99.5 & 0.065 & 0.245 & 0.0645 & 0.13 \\
$\mathrm{Zr}$ & 99.8 & 0.016 & 0.0751 & 0.0571 & 0.094 \\
\hline
\end{tabular}

and deionized water under sonication for $15 \mathrm{~min}$ each, the specimens were sterilized in an autoclave.

\subsection{Ion release test}

The alloy discs (three samples per group) were immersed statically in $6 \mathrm{ml}$ modified SBF solution ( $\mathrm{pH} \mathrm{7.4)}$ at $37^{\circ} \mathrm{C}$ for 30 days. The specimens were removed, and the concentration of metal ions in the SBF solution was measured by Inductively Coupled Plasma-Atomic Emission Spectrometer (PROFILE SPEC, Leeman). The experiment was repeated three times.

\subsection{Cell culture}

The MG63 human osteoblast cell line was provided by The Center for Advanced Research of Central South University, China. The cells were cultured in DMEM supplemented with $10 \% \mathrm{FBS}$ and $1 \%$ penicillin-streptomycin at $37^{\circ} \mathrm{C}, 5 \%$ $\mathrm{CO}_{2}$ and $95 \%$ humidity. The medium was replaced every $48 \mathrm{~h}$, and the cells were passaged at $80 \%$ confluency following trypsin $(0.25 \%)$ digestion, and re-seeded at the appropriate density for in vitro assays.

\subsection{Preparation of alloy extraction medium}

The alloy specimens were immersed in complete DMEM and incubated at $37{ }^{\circ} \mathrm{C}, 5 \% \mathrm{CO}_{2}$ and $95 \%$ humidity for $72 \mathrm{~h}$. The ratio of the disc surface area to the extraction medium volume ratio was 3:1 in accordance with EN ISO standard 10993:12 [29]. The resulting 100\% extraction medium was used for testing cell viability.

\subsection{Live/dead cell assay}

MG63 cells were seeded in a 24-well plate at the density of $2 \times 10^{4}$ cells per well and incubated for $24 \mathrm{~h}$ to facilitate attachment. After replacing the media with $1 \mathrm{ml} 100 \%$ extraction medium, the cells were cultured for another $24 \mathrm{~h}$, washed twice with PBS, and stained with $50 \mu$ l Hoechst $33342(0.25 \%)$ and $50 \mu \mathrm{PI}(0.5 \%)$ at $4{ }^{\circ} \mathrm{C}$ for $20 \mathrm{~min}$. The cells were then rinsed with PBS, and observed under a fluorescence microscope at the excitation wavelengths of 346 and $488 \mathrm{~nm}$. The number of live and dead cells were counted in three random fields per well at $\times 10$ magnification using the Image Proplus6 (ipp6) software.

\subsection{Cell Counting Kit-8 assay}

The MG63 cells were seeded in a 96-well plate at the density of $1 \times 10^{4}$ cells per well, and allowed to adhere for $24 \mathrm{~h}$. The medium was replaced with $1 \mathrm{ml} 100 \%$ extraction medium, and the cells were cultured for 1, 3, and 5 days, 
Table 2 Primers used for RT-PCR analysis

\begin{tabular}{lll}
\hline Gene & Forward primer sequence $\left(5^{\prime}-3^{\prime}\right)$ & Reverse primer sequence $\left(5^{\prime}-3^{\prime}\right)$ \\
\hline GAPDH & CGCTCTCTGCTCCTCCTGT & CCATGGTGTCTGAGCGATGT \\
Ki67 & CCTACCTGGTCTTAGTTCCGT & GTTGGCGTTTCTCCTCTTTTC \\
COL $1 \alpha 1$ & CAACCTCAAGAAGTCCCTGC & AGGTGAATCGACTGTTGCCT \\
ALP & ACTCCAACGCTTACATCAT & CCACTCGTAGTTCTTCTCC \\
OC & TCAGAGATTTCTCCCGGATA & CGCCGCCGGCAGCTCCA \\
Integrin $\beta 1$ & TCACCAAAGTAGAAAGCAG & CAAGGCAAGGCCAATAAGA \\
Cbf 1 & GTCTTACCCCTCCTATCTG & GCCTGGCTCTTCTTACTGA \\
\hline
\end{tabular}

with fresh medium replenished every 2 days. To determine the viability of the cells, $20 \mu \mathrm{l}$ of CCK- 8 test solution (Cell Counting Kit-8; Dojindo, Japan) was added to each well, and the cells were incubated for another $1.5 \mathrm{~h}$. The absorbance at $450 \mathrm{~nm}$ was measured using an ELISA microplate reader (Molecular Devices, USA). Sterile culture media was used as the negative control, and cells incubated in $100 \%$ cpTi extraction medium as the positive control. Each sample was measured four times.

\subsection{Acridine orange (AO) staining}

MG63 cells were seeded on alloy surfaces at the density of $1 \times 10^{4}$ cell per well in complete DMEM, and cultured for 6 , 24 , and $48 \mathrm{~h}$. After washing twice with PBS, the cells were fixed with $95 \%$ alcohol for $10 \mathrm{~min}$, air dried, and stained with $300 \mu$ l acridine orange $(0.01 \%)$ per well for $5 \mathrm{~min}$. The stained cells were rinsed with PBS for $1 \mathrm{~min}$, cleared with $0.1 \mathrm{mM}$ calcium chloride for $1 \mathrm{~min}$, and rinsed again. The cells were observed under a fluorescence microscope at an excitation wavelength of $518 \mathrm{~nm}$. The number of stained cells were counted in five random fields at $\times 10$ magnification, using the Image Proplus6 (ipp6) software. The experiment was repeated thrice.

\subsection{Scanning electron microscopy (SEM)}

MG63 cells were seeded on the alloy surfaces at the density of $1 \times 10^{4}$ cells per well, and cultured in complete DMEM for $6 \mathrm{~h}, 48 \mathrm{~h}$, and 9 days. The cells were fixed with $2.5 \%$ glutaraldehyde for $40 \mathrm{~min}$, rinsed with PBS, and dehydrated through an ethanol gradient $(25,50,75,90,95,100 \%)$ for $15 \mathrm{~min}$. After vacuum drying for $12 \mathrm{~h}$, the specimens were sputter coated with $10 \mathrm{~nm}$ gold and observed under the Hitachi S-4800N field emission SEM.

\subsection{Real-time polymerase chain reaction (RT-PCR)}

The MG63 cells were seeded on the different alloy surfaces at the density of 10,000 cells per well, and cultured for 3, 6, 9, and 12 days in complete DMEM. Total RNA was extracted from the cells using Omega R6934-01 Total RNA
Table 3 Mechanical properties of cpTi and the Ti-xZr alloys $(x=5$, $15,25,35,45 \mathrm{wt} \%)$

\begin{tabular}{llrl}
\hline Alloys & $\begin{array}{l}\text { Vickers } \\
\text { hardness }(\mathrm{HV})\end{array}$ & $\begin{array}{l}\text { Compressive } \\
\text { strength }(\mathrm{Mpa})\end{array}$ & $\begin{array}{l}\text { Elastic } \\
\text { modulus (Gpa) }\end{array}$ \\
\hline $\mathrm{Ti}$ & $292 \pm 6.23$ & $786 \pm 17.22$ & $103 \pm 3.28$ \\
$\mathrm{Ti}-5 \mathrm{Zr}$ & $473 \pm 10.17$ & $1279.8 \pm 20.28$ & $59.3 \pm 6.12$ \\
$\mathrm{Ti}-15 \mathrm{Zr}$ & $481 \pm 4.89$ & $1367.9 \pm 37.12$ & $54.6 \pm 5.57$ \\
$\mathrm{Ti}-25 \mathrm{Zr}$ & $495 \pm 8.26$ & $1416.5 \pm 22.36$ & $53.5 \pm 6.45$ \\
$\mathrm{Ti}-35 \mathrm{Zr}$ & $513 \pm 11.22$ & $1435.8 \pm 16.25$ & $55.5 \pm 8.37$ \\
$\mathrm{Ti}-45 \mathrm{Zr}$ & $525 \pm 9.08$ & $1599.8 \pm 37.21$ & $53.9 \pm 6.09$ \\
\hline
\end{tabular}

Kit II (BioTek, USA) and reversed transcribed to cDNA with the PrimeScript RT Master Mix (Takara) according to the manufacturers' instructions. RT-PCR was performed using SYBR Premix Ex Taq II (Takara) on the CFX96 PCR System (Bio-Rad). Relative expression levels of Ki67, COLI- $\alpha 1$, ALP, OC, integrin $\beta 1$, and Cbf $\alpha-1$ were calculated in terms of the comparative cycle threshold $(\mathrm{Ct})$ as $2^{(-\Delta \Delta \mathrm{Ct})}$, with GAPDH as the internal control. The primer sequences are shown in Table 2.

\subsection{Statistical analysis}

The experimental data were expressed as the mean \pm standard deviation of three replicates, and compared by twoway analysis of variance followed by Tukey's multiple comparison test. $p<0.05$ with a $95 \%$ confidence interval was considered statistical significance. GraphPad Prism 6 software (GraphPad Software Inc. La Jolla, CA, USA) was used for statistical analysis.

\section{Results}

\subsection{Ti-xZr alloys are mechanically superior to cpTi}

The mechanical properties of $\mathrm{Ti}-\mathrm{xZr}$ alloys are summarized in Table 3, and indicate that the bending strength and compressive strength of the alloys increased with $\mathrm{Zr}$ content. $\mathrm{Ti}-45 \mathrm{Zr}$ exhibited the maximum bending and compressive strength values of 867.1 and $1599.8 \mathrm{MPa}$ respectively, 
Table $4 \mathrm{Ti}$ and $\mathrm{Zr}$ ions in SBF

\begin{tabular}{lll}
\hline Alloys & Alloying elements & Ion concentration $(\mu \mathrm{g} / \mathrm{l})$ \\
\hline $\mathrm{Cp}-\mathrm{Ti}$ & $\mathrm{Ti}$ & $0.003 \pm 0.0007$ \\
$\mathrm{Ti}-5 \mathrm{Zr}$ & $\mathrm{Ti}$ & $0.002 \pm 0.0005$ \\
& $\mathrm{Zr}$ & $0.001 \pm 0.0002$ \\
$\mathrm{Ti}-15 \mathrm{Zr}$ & $\mathrm{Ti}$ & $0.002 \pm 0.0002$ \\
& $\mathrm{Zr}$ & $0.001 \pm 0.0003$ \\
$\mathrm{Ti}-25 \mathrm{Zr}$ & $\mathrm{Ti}$ & $0.001 \pm 0.0002$ \\
& $\mathrm{Zr}$ & $0.001 \pm 0.0002$ \\
$\mathrm{Ti}-35 \mathrm{Zr}$ & $\mathrm{Ti}$ & $0.002 \pm 0.0003$ \\
& $\mathrm{Zr}$ & $0.001 \pm 0.0001$ \\
$\mathrm{Ti}-45 \mathrm{Zr}$ & $\mathrm{Ti}$ & $0.001 \pm 0.0002$ \\
& $\mathrm{Zr}$ & $0.001 \pm 0.0003$ \\
\hline
\end{tabular}

which are significantly higher compared to that of cpTi. The elastic modulus of the alloys ranged from $53.5 \mathrm{GPa}$ for $\mathrm{Ti}-35 \mathrm{Zr}$ to $59.3 \mathrm{GPa}$ for $\mathrm{Ti}-\mathrm{xZr}$, and were markedly lower than that of cpTi $(103 \mathrm{GPa})$.

\subsection{Ti-xZr alloys are stable in vitro}

The stability of the different alloys was evaluated by measuring the amount of ions released into the SBF. As shown in Table 4, less $\mathrm{Ti}$ or $\mathrm{Zr}$ ions were released from the $\mathrm{Ti}-\mathrm{xZr}$ alloys compared to cpTi, which can be attributed to the formation of stable corrosion resistant films on the alloys.

\subsection{Ti-xZr alloys are biocompatible}

The biocompatibility of the Ti-xZr alloys was determined by analyzing the viability and proliferation of the MG63 cells grown in the alloy extraction media or on the different alloy surfaces. As shown in Fig. 1, very few dead cells were detected following $24 \mathrm{~h}$ incubation with the different $100 \%$ extraction media, and $\sim 97 \%$ cells were viable. In addition, the viability was slightly higher in the $\mathrm{Ti}-\mathrm{xZr}$ alloys compared to the cpTi group.

The proliferation rates of the MG63 cells cultured in the different $100 \%$ extraction media were also measured over a period of 5 days. As shown in Fig. 2, the number of cells increased steadily in a time-dependent manner in all groups, and the proliferation rate was $\sim 80 \%$ on day 5 as compared to day $1(p<0.001)$. Furthermore, the viability and proliferation rates of cells cultured in the $100 \%$ extraction media of all but the $\mathrm{Ti}-15 \mathrm{Zr}$ and $\mathrm{Ti}-35 \mathrm{Zr}$ alloys were comparable to that of cells grown in cpTi extraction medium $(p<0.05)$.

Consistent with the above, the MG63 grown on the surface of the different alloys were also viable over a period of $48 \mathrm{~h}$. As shown in Fig. 3a, the cells were able to attach to the metal surface within $6 \mathrm{~h}$, and proliferated rapidly for
$48 \mathrm{~h}$. Furthermore, the total number of cells at 6 and $24 \mathrm{~h}$ were significantly higher on $\mathrm{Ti}-5 \mathrm{Zr}$ samples compared to the others at each time point $\left(*^{*} p<0.01\right)$. The cell count increased significantly in all groups by $48 \mathrm{~h}$, and was highest on $\mathrm{Ti}-45 \mathrm{Zr}(* * * p<0.001)$, and least on the Ti-25Zr alloys $(* * * p<0.001)$ (Fig. 3b). Taken together, the $\mathrm{Ti}-\mathrm{xZr}$ alloys are non-toxic and can support the growth of osteoblasts, and $\mathrm{Ti}-45 \mathrm{Zr}$ shows greater biocompatibility compared to cpTi.

\subsection{The Ti-xZr alloys supported cellular adhesion and spread}

The adhesion, differentiation, and migration of the MG63 cells on the cpTi and different alloy surfaces were analyzed by SEM. As shown in Fig. 4, the cells adhered to all surfaces within $6 \mathrm{~h}$, and exhibited typical ellipse-like morphology while covering $40-50 \%$ of the area. By $48 \mathrm{~h}$, the cells had acquired a spindle-like morphology with uniform spread and prominent filopodia extending in all directions. In addition, $\sim 70 \%$ of the surface area of all specimens except that of $\mathrm{Ti}-35 \mathrm{Zr}$ was occupied with the growing cells, which also showed considerable overlap indicating healthy growth. After 9 days, the surfaces of all specimens were completely covered by a highly dense cellular monolayer with multiple filopodia-like intercellular connections protruding from the edges of cells. The filopodia were particularly extensive along the leading edges of the cells. Thus, the $\mathrm{Ti}-\mathrm{xZr}$ alloys allow osteoblast adhesion and growth comparable to that on cpTi.

\subsection{Ti-xZr alloys induced osteogenic differentiation}

The osteogenic capacity of the different alloys was determined by analyzing the expression levels of osteogenesisrelated genes in MG63 cells cultured for 3, 6, 9, and 12 days on cpTi and Ti-xZr alloys. As shown in Fig. 5c, COLI- $\alpha 1$ levels peaked on the 3rd day of culture and declined thereafter in all groups, and was similar between cpTi and the $\mathrm{Ti}-\mathrm{xZr}$ alloys except $\mathrm{Ti}-35 \mathrm{Zr}$, which showed lower expression compared to cpTi. In contrast, ALP (Fig. 5d), Cbf $\alpha-1$ (Fig. 5e), and OC (Fig. 5f) were significantly downregulated in the cells grown on $\mathrm{Ti}-5 \mathrm{Zr}$, $\mathrm{Ti}-15 \mathrm{Zr}$, and Ti-25Zr on days 9 and 12 compared to that in the cpTi group $(p<0.001)$. Interestingly, Ki67 levels were lower in the $\mathrm{Ti}-5 \mathrm{Zr}$ and $\mathrm{Ti}-15 \mathrm{Zr}$ groups compared to that in cp Ti on day $9(p<0.01)$, but significantly higher in $\mathrm{Ti}-35 \mathrm{Zr}$ and Ti-45Z groups $(p<0.001)$ (Fig. 5a). Furthermore, integrin $\beta 1$ levels in $\mathrm{Ti}-5 \mathrm{Zr}, \mathrm{Ti}-15 \mathrm{Zr}$, and $\mathrm{Ti}-25 \mathrm{Zr}$ were significantly lower relative to the cpTi group on day 3 ( $p<$ 0.05) (Fig. 5b). To summarize, Ti-45Zr showed the maximum osteogenic activity compared to the other alloys, almost comparable to that of cpTi. 

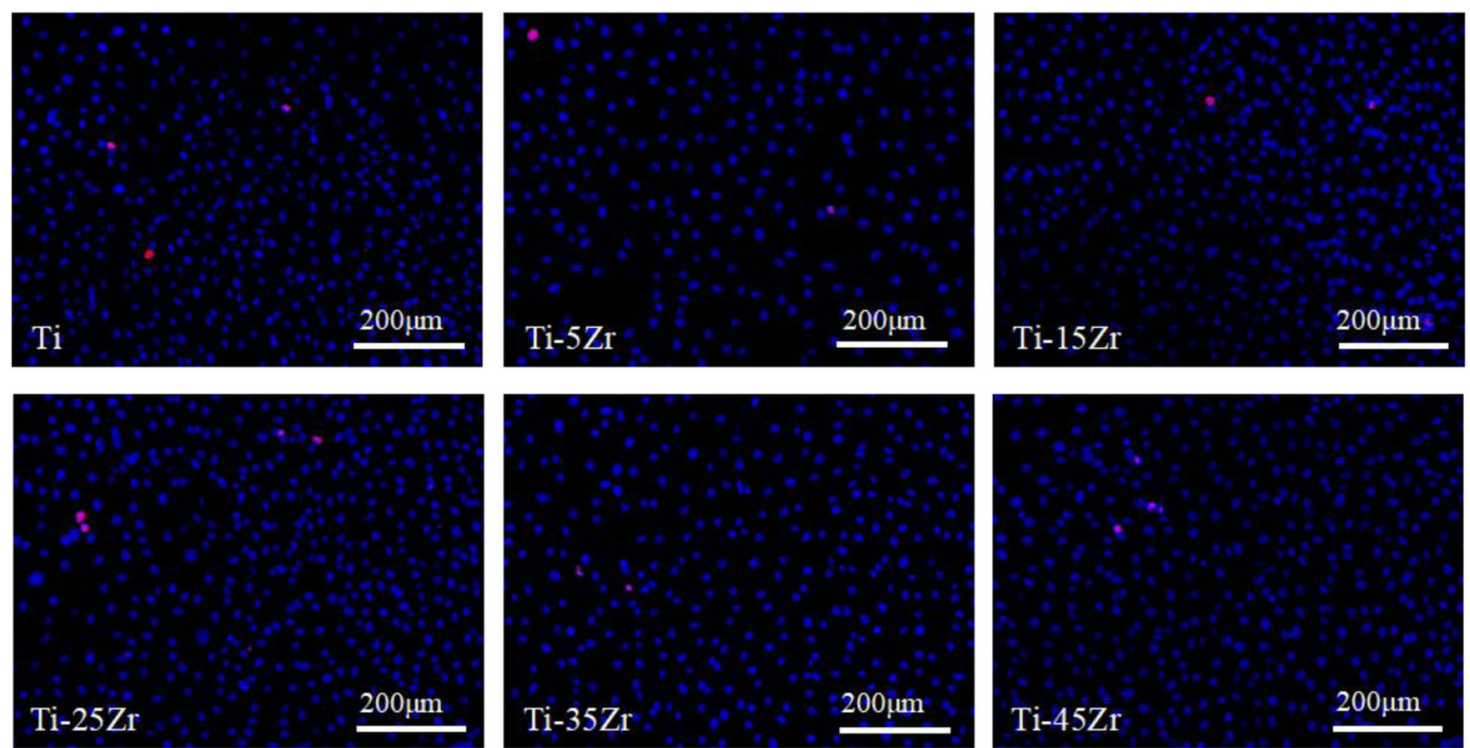

Fig. 1 Representative fluorescence microscopy images showing Hoechst 3342 and PI-stained live (blue) and dead (red) cells after $24 \mathrm{~h}$ of incubation with different $100 \%$ extraction media

Fig. 2 CCK-8 assays of the proliferation of cells cultured in $100 \%$ extraction medium of Ti-xZr alloys $(5,15,25,35$, and $45 \% \mathrm{Zr}$ ) and cpTi on days 1,3 , and 5 , with cpTi as control. Data are expressed as mean $\pm \mathrm{SD}$

$(n=3) . * p<0.05, * * * p<0.001$

\section{The viability of cell}

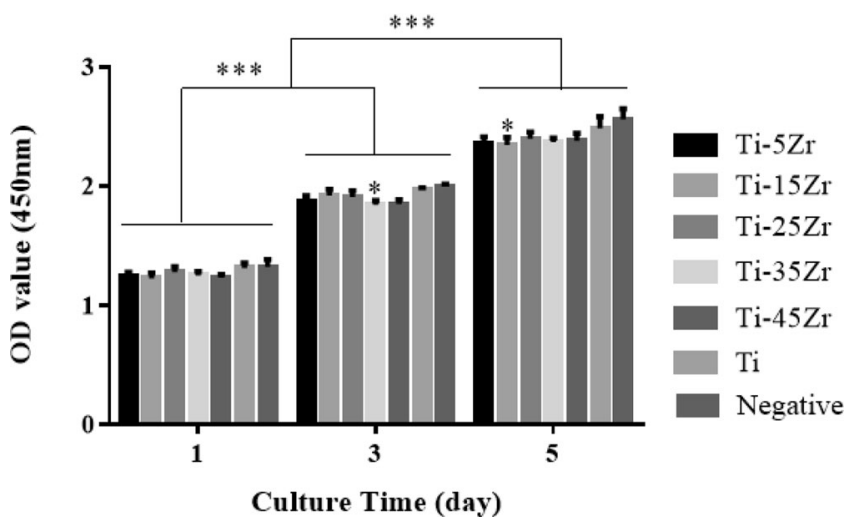

resistance and low elastic modulus [28]. In the present study, we evaluated the biocompatibility and osteogenic capacity of these alloys to determine their potential as dental implants.

Biocompatibility is an essential criterion for a medical implant, which should not cause any thrombogenic, toxic, allergic, or inflammatory responses in vivo. $\mathrm{Ti}$ dental implants usually fail due to the allergic reaction to $\mathrm{Ti}$ ions that leach from the alloys, eventually leading to inflammation in the surrounding tissues [38, 39]. Wachi et al. reported that $\mathrm{Ti}$ ions are the causative factor of peri-implant mucositis, which can progress to peri-implantitis accompanied by alveolar bone resorption [5]. Therefore, dental implant materials with high corrosion resistance are urgently needed. We tested the corrosion of the Ti-Zr alloys in SBF, and detected only miniscule amounts of $\mathrm{Ti}$ and $\mathrm{Zr}$ ions in the solution after 30 days of incubation. The higher showed good mechanical properties, excellent corrosion 


\section{(a)}
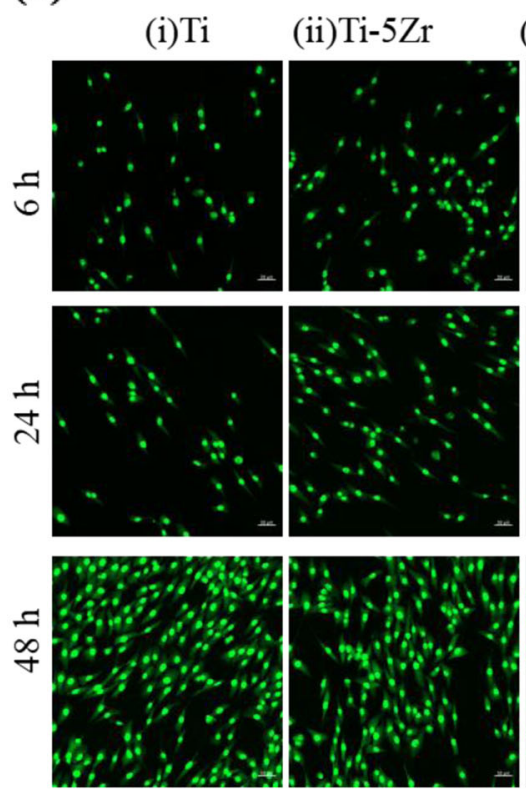

(ii) $\mathrm{Ti}-5 \mathrm{Zr}$

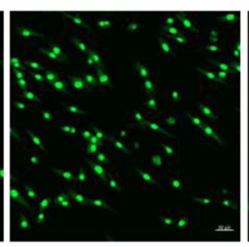

(iii) $\mathrm{Ti}-15 \mathrm{Zr}$
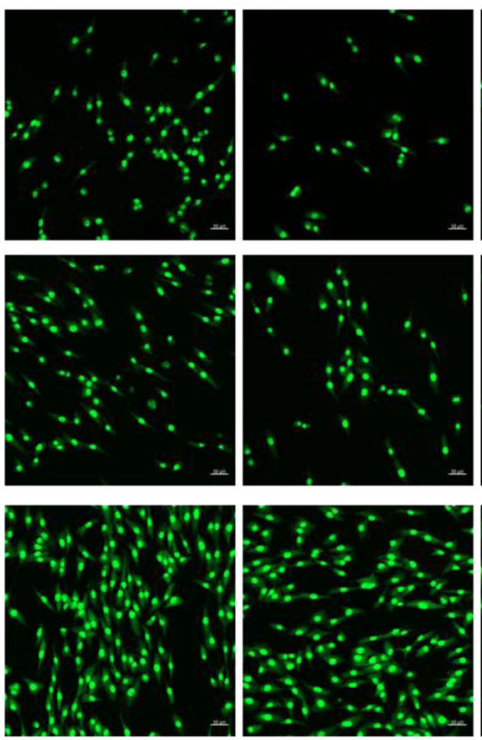

(iv)Ti-25Zr

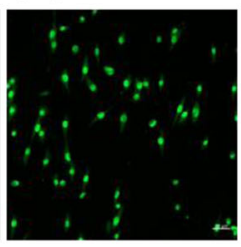

(v) Ti-35Zr
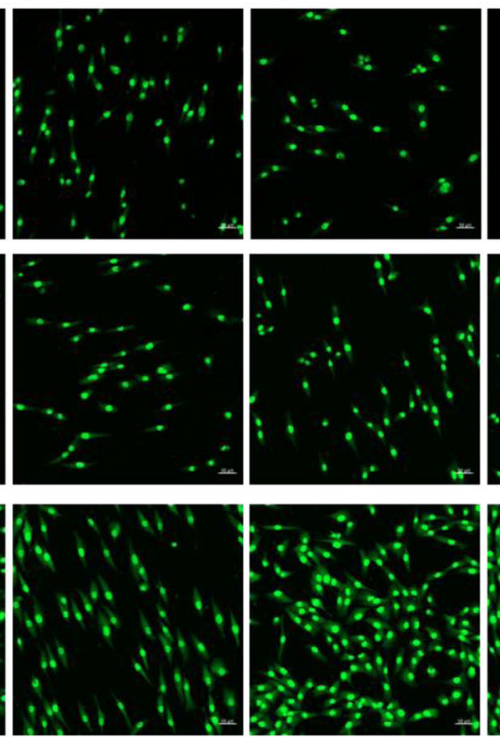

(vi) Ti-45Zr
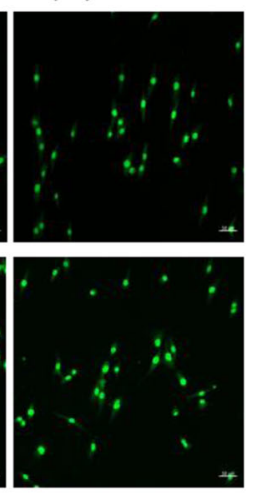

(b)

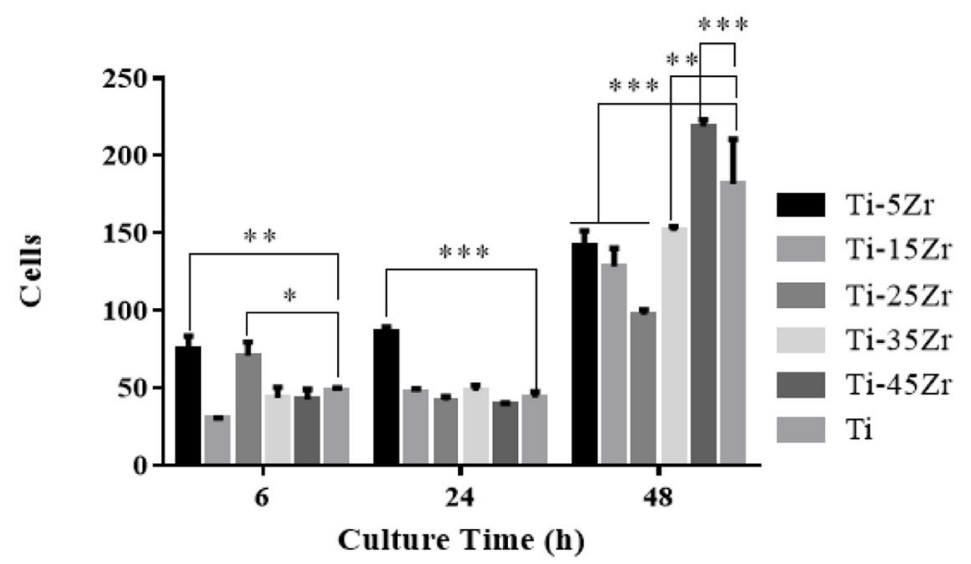

Fig. 3 a Representative fluorescence microscopy images showing acridine orange-stained MG63 cells cultured for 6,24 , and $48 \mathrm{~h}$ on (i) $\mathrm{Ti}$, (ii) $\mathrm{Ti}-5 \mathrm{Zr}$, (iii) $\mathrm{Ti}-15 \mathrm{Zr}$, (iv) $\mathrm{Ti}-25 \mathrm{Zr}$, (v) $\mathrm{Ti}-35 \mathrm{Zr}$, and (vi)

Ti-45Zr. Scale is $50 \mu \mathrm{m}$. b The number of viable cells at the different time points in the indicated groups. Data are expressed as mean $\pm \mathrm{SD}$ $(n=3) . * p<0.05 ; * * p<0.01 ; * * * p<0.001$

stability of Ti-Zr alloys compared to cpTi can be attributed to the formation of corrosion resistant oxide films on the alloy surface. Consistent with our results, Akimoto et al. found that $90 \%$ less $\mathrm{Ti}$ ions were released from $\mathrm{Ti}-30 \mathrm{Zr}$ compared to pure Ti after 1 week of immersion in physiological fluid. This indicates that the $\mathrm{ZrO}_{2}$ film is more stable and resilient to dissolution compared to the oxide of $\mathrm{Ti}$, and addition of $\mathrm{Zr}$ can significantly reduce $\mathrm{Ti}$ ion dissolution [27]. Therefore, binary Ti-Zr alloys have gained considerable attention in biomedical applications on account of their higher mechanical strength [40, 41], corrosion resistance [42], and biocompatibility compared to cpTi [31, 43].

The cytocompatibility of the $\mathrm{Ti}-\mathrm{Zr}$ alloys was evaluated in the MG63 osteoblast cell line. This line was originally isolated from human osteosarcoma, and retains the osteogenic characteristics along with the advantage of unlimited growth [44]. In recent years, they have completely replaced osteoblasts for analyzing the cytotoxicity of biomaterials in vitro [45]. However, in the study of cell morphology and osteogenic differentiation, MSCs cells with differentiation potential have more advantages [46]. The alloys were highly conducive to the survival and proliferation of MG63 cells, which is consistent with the general biosafety of $\mathrm{Zr}$ [47]. Cell adhesion to the implant surface is crucial for the subsequent growth, differentiation, and migration [48]. We found that the MG63 cells adhered to, spread and rapidly proliferated on the alloy surfaces. Consistent with our results, Saldana et al. also showed [49] that osteoblasts can attach to coarse-grain or fine-grain $\mathrm{Zr}$ surfaces, and subsequently spread, proliferate, differentiate, 
Fig. 4 Representative SEM images showing the morphology of cells frown on different surfaces for $6 \mathrm{~h}, 48 \mathrm{~h}$, and 9 days
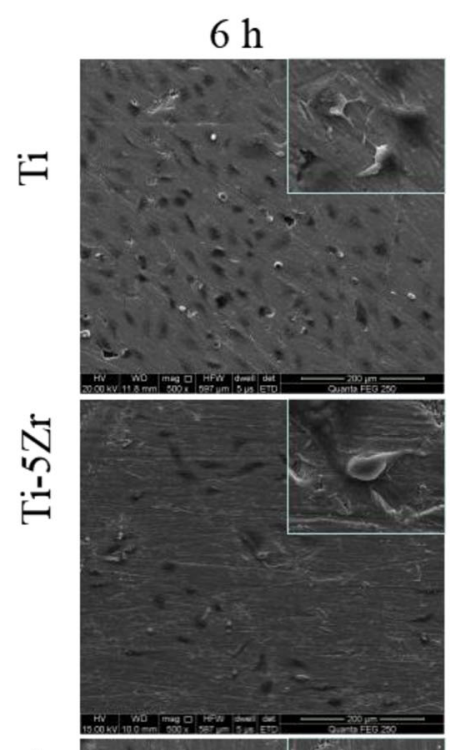

$$
\text { in }
$$
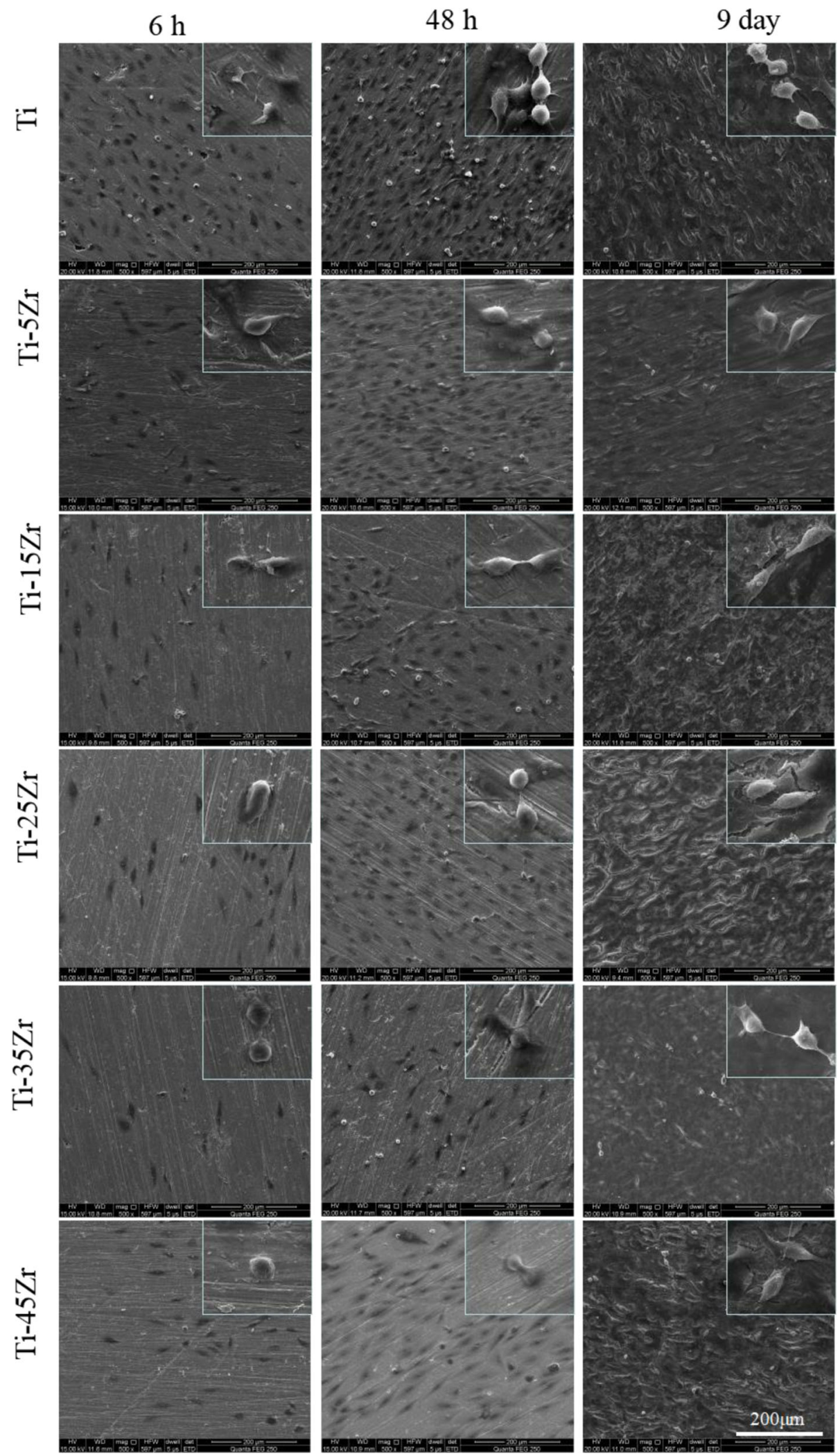

and mature to a similar extent as on the Ti6Al4V alloy. Furthermore, the $\mathrm{ZnO}_{2}$ film can also promote cellular adhesion, proliferation, and differentiation [50], thus underscoring the suitability of $\mathrm{Ti}-\mathrm{Zr}$ alloys as surfaces for osteoblast growth [51]. The differentiation of osteoblasts into mature osteocytes involves proliferation, extracellular 
(a)

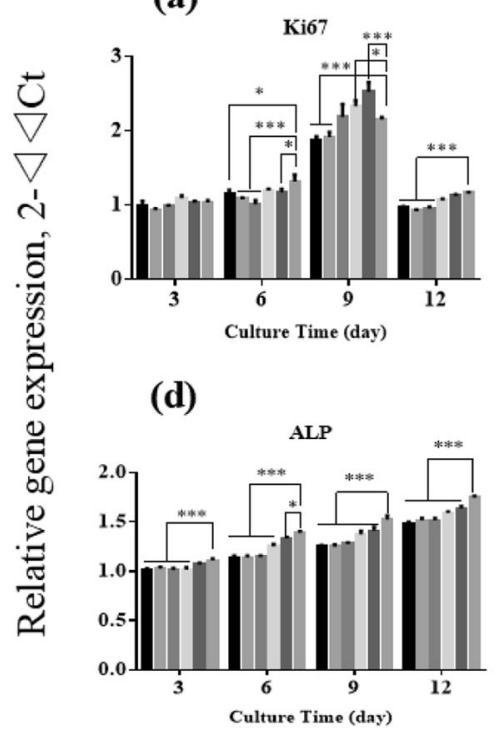

(b)

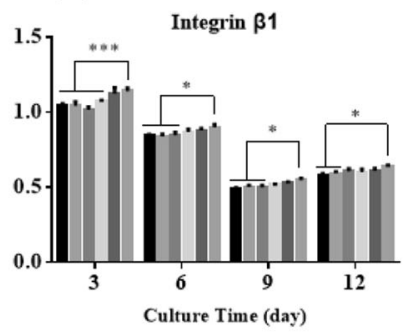

(e)

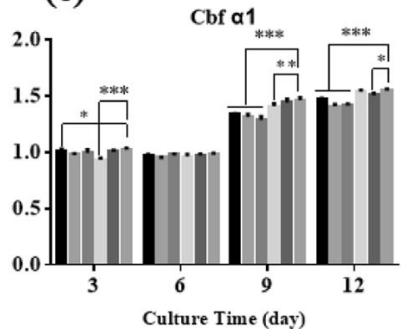

(c)

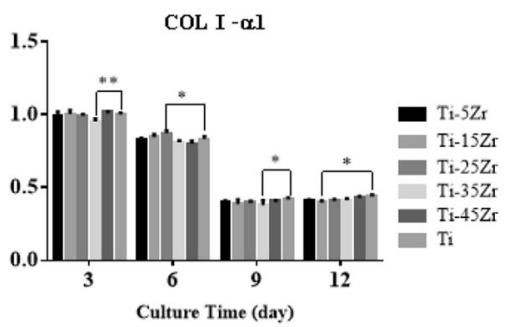

(f)

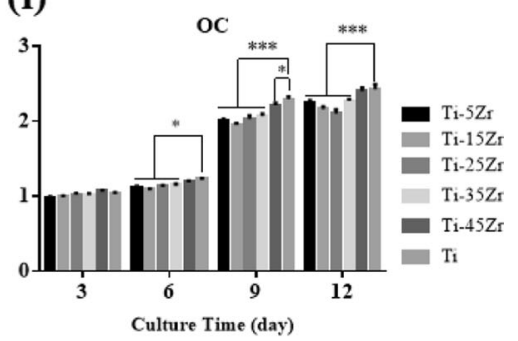

Fig. 5 The induction of osteoblast differentiation-related genes in MG63 cells cultured on the different surfaces. Relative expression levels of (a) Ki67, (b) Integrin $\beta 1$, (c) COLI- $\alpha 1$, (d) ALP, (e) Cbf $\alpha 1$, and (f) OC in the indicated groups. Data are expressed as mean \pm SD $(n=3) . * p<0.05 ; * * p<0.01 ; * * * p<0.001$

Science Foundation of Hunan Province (Nos. 2020JJ5862 and 2020JJ5985).

\section{Compliance with ethical standards}

Conflict of interest The authors declare no competing interests.

Publisher's note Springer Nature remains neutral with regard to jurisdictional claims in published maps and institutional affiliations.

Open Access This article is licensed under a Creative Commons Attribution 4.0 International License, which permits use, sharing, adaptation, distribution and reproduction in any medium or format, as long as you give appropriate credit to the original author(s) and the source, provide a link to the Creative Commons license, and indicate if changes were made. The images or other third party material in this article are included in the article's Creative Commons license, unless indicated otherwise in a credit line to the material. If material is not included in the article's Creative Commons license and your intended use is not permitted by statutory regulation or exceeds the permitted use, you will need to obtain permission directly from the copyright holder. To view a copy of this license, visit http://creativecommons. org/licenses/by/4.0/.

\section{References}

1. Fernandez-Estevan L, Selva-Otaolaurruchi EJ, Montero J, SolaRuiz F. Oral health-related quality of life of implant-supported overdentures versus conventional complete prostheses: retrospective study of a cohort of edentulous patients. Med Oral Patol Oral Cir Bucal. 2015;20:450-8.

2. Geetha M, Singh AK, Asokamani R, Gogia AK. Ti based biomaterials, the ultimate choice for orthopedic implants-a review. Prog Mater Sci. 2009;54:259-64.
Acknowledgements This work was partly supported by the National Natural Science Foundation of China (No. 51904357) and the Natural 
3. Chen Q, Thouas GA. Metallic implant biomaterials. Mater Sci Eng R. 2015;87:1-57.

4. Gealh WC, Mazzo V, Barbi F, Camarini ET. Osseointegrated implant fracture: causes and treatment. J Oral Implantol. 2011;37:499-503.

5. Wachi T, Shuto T, Shinohara Y, Matono Y, Makihira S. Release of titanium ions from an implant surface and their effect on cytokine production related to alveolar bone resorption. Toxicology. 2015;327:1-9.

6. Cordeiro JM, Barão VAR. Is there scientific evidence favoring the substitution of commercially pure titanium with titanium alloys for the manufacture of dental implants? Mater Sci Eng C. 2017;71:1201-15.

7. Hacisalihoglu I, Samancioglu A, Yildiz F, Purcek G, Alsaran A. Tribocorrosion properties of different type titanium alloys in simulated body fluid. Wear. 2015;332-333:679-86.

8. Mishnaevsky L, Levashov E, Valiev RZ, Segurado J, Sabirov I, Enikeev N, et al. Nanostructured titanium-based materials for medical implants: modeling and development. Mater Sci Eng R Rep. 2014;81:1-19.

9. Miura K, Yamada N, Hanada S, Jung T, Itoi KE. The bone tissue compatibility of a new Ti-Nb-Sn alloy with a low Young's modulus. Acta Biomater. 2011;7:2320-6.

10. Catalani S, Stea S, Beraudi A, Gilberti ME, Bordini B, Toni A. Vanadium release in whole blood, serum and urine of patients implanted with a titanium alloy hip prosthesis. Clin Toxicol. 2013;51:550-6.

11. Kaufman AM, Alabre CI, Rubash HE, Shanbhag AS. Human macrophage response to UHMWPE, TiAlV, CoCr, and alumina particles: analysis of multiple cytokines using protein arrays. J Biomed Mater Res A. 2008;84:464-74.

12. Liu N, Meng J, Wang Z, Zhou G, Shi T, Zhao J. Autophagy mediated $\mathrm{TiAl}(6) \mathrm{V}(4)$ particle-induced peri-implant osteolysis by promoting expression of TNF-alpha. Biochem Biophys Res Commun. 2016;473:133-9.

13. Mirza A, King A, Troakes C, Exley C. Aluminium in brain tissue in familial Alzheimer's disease. J Trace Elem Med Biol. 2017;40:30-6.

14. Okamoto H. Sn-Zr (Tin-Zirconium). J Phase Equilib Diff. 2010;31:411-2.

15. AlFarraj AA, Sukumaran A, Al Amri MD, Van Oirschot AB, Jansen JA. A comparative study of the bone contact to zirconium and titanium implants after 8 weeks of implantation in rabbit femoral condyles. Odontology. 2018;106:37-44.

16. Wen B, Zhu F, Li Z, Zhang P, Lin X, Dard M. The osseointegration behavior of titanium- zirconium implants in ovariectomized rabbits. Clin Oral Implants Res. 2014;25:819-25.

17. Grandin HM, Berner S, Dard M. A review of titanium zirconium (TiZr) alloys for use in endosseous dental implants. Materials. 2012;5:1348-60.

18. Liu X, Chen S, Tsoi JKH, Martinlinna JP. Binary titanium alloys as dental implant materials - a review, regenerative. Biomaterials. 2017;5:315-23.

19. Wen CE, Yamada Y, Hodgson PD. Fabrication of novel TiZr alloy foams for biomedical applications. Mater Sci Eng C. 2006;26:1439-44.

20. Ho WF, Cheng CH, Pan CH, Wu SC, Hsu HC. Structure, mechanical properties and grindability of dental Ti-10Zr-X alloys. Mater Sci Eng C. 2009;29:36-43.

21. Sista S, Nouri A, Li Y, Wen C, Hodgson PD, Pande G. Cell biological responses of osteoblasts on anodized nanotubular surface of a titanium-zirconium alloy. J Biomed Mater Res A. 2013;101:3416-30.

22. Oliveira NTC, Ferreira EA, Duarte LT, Biaggio SR, Rocha-Filho RC, Bocchi N. Corrosion resistance of anodic oxides on the $\mathrm{Ti}-50 \mathrm{Zr}$ and $\mathrm{Ti}-13 \mathrm{Nb}-13 \mathrm{Zr}$ alloys. Electrochim Acta. 2006;51:2068-75.
23. Oliveira NT, Biaggio SR, Rocha-Filho RC, Bocchi N. Electrochemical studies on zirconium and its biocompatible alloys Ti$50 \mathrm{Zr}$ at. $\%$ and $\mathrm{Zr}-2.5 \mathrm{Nb}$ wt.\% in simulated physiologic media. $\mathrm{J}$ Biomed Mater Res A. 2005;74:397-407.

24. Kobayashi E, Matsumoto S, Doi H, Yoneyama T, Hamanaka H. Mechanical-properties of the binary titanium-zirconium alloys and their potential for biomedical materials. J Biomed Mater Res. 1995;29:943-50.

25. Ho WF, Chen WK, Wu SC, Hsu HC. Structure, mechanical properties, and grindability of dental Ti-Zr alloys. J Mater Sci Mater Med. 2008;19:3179-86.

26. Hsu HC, Wu SC, Sung YC, Ho WF. The structure and mechanical properties of as-cast $\mathrm{Zr}$-Ti alloys. $\mathrm{J}$ Alloy Compd. 2009;488:279-83.

27. Teisuke A, Takeshi U, Yusuke T, Hisashi D, Takao H, Noriyuki $\mathrm{W}$. Evaluation of corrosion resistance of implant-use Ti-Zr binary alloys with a range of composition. J Biomed Mater Res B: Appl Biomater. 2018;106:73-9.

28. Baoqi W, Wei R, Jue L, Taomei ZH, Hailin Y, Jianming R. Microstructure, mechanical properties, and preliminary biocompatibility evaluation of binary $\mathrm{Ti}-\mathrm{Zr}$ alloys for dental application. J Biomater Appl. 2019;33:766-75.

29. International Organization for Standardization. ISO-10993-12: biological evaluation of medical devices part 12: sample preparation and reference materials. Arlington, VA: ANSI/AAMI; 2007.

30. Wen B, Zhu F, Li Z, Zhang P. The osseointegration behavior of titanium-zirconium implants in ovariectomized rabbits. Clin Oral Implants Res. 2014;25:819-25.

31. Sista S, Wen CE, Hodgson PD, Pande G. The influence of surface energy of titanium-zirconium alloy on osteoblast cell functions in vitro. J Biomed Mater Res A. 2011;97:27-36.

32. Saulacic N, Bosshardt D, Bornstein M, Berner S, Buser D. Bone apposition to a titanium-zirconium alloy implant, as compared to two other titanium-containing implants. Eur Cell Mater. 2012;23:273-86.

33. Bolat G, Izquierdo J, Santana JJ, Mareci D, Souto RM. Electrochemical characterization of ZrTi alloys for biomedical applications. Electrochim Acta. 2013;88:447-56.

34. Arifin A, Sulong AB, Muhamad N, Syarifa J, Ramli MI. Material processing of hydroxyapatite and titanium alloy (HA/Ti) composite as implant materials using powder metallurgy: a review. Mater Des. 2014;55:165-75.

35. Froes FH. Titanium powder metallurgy: a review-part 1. Advanced Materials \& Processes; Asm INT, Subscriptions Specialist Customer Service, Materials Park, OH 44073-0002 USA, 2012. pp. 16-22.

36. Wang H, Fang ZZ, Sun PA. Critical review of mechanical properties of powder metallurgy titanium. Int $\mathrm{J}$ Powder Metall. 2010;46:545-57.

37. Ljerka S, Anita S, Zoran G. Synthesis of Ti-Zr alloy by powder metallurgy. Eng Rev. 2019;39:115-23.

38. Fretwurst T, Nelson K, Tarnow DP, Wang HL, Giannobile WV. Is metal particle release associated with Peri-implant bone destruction? An emerging concept. J Dent Res. 2018;97:259-65.

39. Noronha OM, Schunemann WVH, Mathew MT. Can degradation products released from dental implants affect peri-implant tissues? J Periodontal Res. 2018;53:1-11.

40. Grandin HM, Berner S, Dard M. A review of titanium zirconium (TiZr) alloys for use in endosseous dental implants. Materials (Basel). 2012;5:1348-60.

41. Correa DRN, Vicente FB, Donato TAG, Arana-Chavez VE, Buzalaf MAR, Grandini CR. The effect of the solute on the structure, selected mechanical properties, and biocompatibility of Ti-Zr system alloys for dental applications. Mater Sci Eng C. 2014;34:354-9. 
42. Akimoto T, Ueno T, Tsutsumi Y, Doi H, Hanawa T, Wakabayashi $\mathrm{N}$. Evaluation of corrosion resistance of implant-use Ti-Zr binary alloys with a range of compositions. J Biomed Mater Res B Appl Biomater. 2018;106:73-9.

43. Ikarashi Y, Toyoda K, Kobayashi E, Doi H, Yoneyama T, Hamanaka $\mathrm{H}$, et al. Improved biocompatibility of titaniumzirconium (Ti-Zr) alloy: tissue reaction and sensitization to $\mathrm{Ti}-\mathrm{Zr}$ alloy compared with pure $\mathrm{Ti}$ and $\mathrm{Zr}$ in rat implantation study. $\mathrm{J}$ Jpn Inst Met. 2007;71:395-401.

44. Johnson WL. Bulk glass-forming metallic alloys: Science and technology. MRS Bull. 1999;24:42-56.

45. Lin HT, Cheng HY. Study on cell behavior on surfaces with various nanostructured modifications. J Biomater Tiss Eng. 2019;9:1021-6.

46. Sun XY, Su W, Ma XM, Zhang HY, Sun Z, Li XD. Comparison of osteogenic capability of rat bone mesenchymal stem cells on collagen, collagen/hydroxyapatite, hydroxyapatite and biphasic calcium phosphate. Regenerative Biomater. 2018;5:93-103.

47. Dongmei ZH, Cynthia SW, Cuie W, Yuncang L. Cellular responses of osteoblast-like cells to 17 elemental metals. J Biomed Mater Res Part A. 2017;105:148-58.
48. Dai Y, Liu H, Liu B, Wang Z, Li Y, Zhou G. Porous $\beta$-Ca2SiO4ceramic scaffolds for bone tissue engineering: in vitro and in vivo characterization. Ceram Int. 2015;41:5894-902.

49. Saldaña L, Mendéz-Vilas A, Jiang L, Multigner M, GonzálezCarrasco JL, Pérez-Prado MT, et al. In vitro biocompatibility of an ultrafine grained zirconium. Biomaterials. 2007;28: 4343-54.

50. Josset Y, Oum'Hamed Z, Zarrinpour A, Lorenzato M, Adnet JJ, Laurent-Maquin D. In vitro reactions of human osteoblasts in culture with zirconia and alumina ceramics. J Biomed Mater Res. 1999;47:481-93.

51. Sista S, Nouri A, Li Y. Cell biological responses of osteoblasts on anodized nanotubular surface of a titanium-zirconium alloy. J Biomed Mater Res A. 2013;101:3416-30.

52. Chen Y, Roohani-Esfahani SI, Lu Z, Zreiquat H, Dunstan CR. Zirconium ions up-regulate the BMP/SMAD signaling pathway and promote the proliferation and differentiation of human osteoblasts. PLoS ONE. 2015;10:1-17.

53. Lee BA, Kim HJ, Park YJ, Chung HJ, Kim YJ. Osteoblastic behavior to zirconium coating on Ti-6Al-4V alloy. J Adv Prosthodont. 2014;5:512-20. 